\title{
INTEGRATION OF NOBLE MORAL VALUES IN INDONESIAN LANGUAGE LEARNING MATERIALS TO FOSTER STUDENT LANGUAGE POLITENESS IN AD-DIMYATI BANDUNG INTEGRATED VOCATIONAL SCHOOL (SMK TERPADU)
}

\author{
Ifah Khadijah \\ Program Studi Pendidikan Guru Madrasah Ibtidaiyah (PGMI) \\ FAI Universitas Islam Nusantara Bandung \\ Email: ifahkhadijah@uninus.ac.id
}

\begin{abstract}
The importance of learning noble moral values, morals and nobility for all citizens of the nation should not be denied anymore. A country or a nation can collapse because officials and some of their people behave immorally. Immoral behavior will lead to riots, confusion, irregularities and others that cause the destruction of a nation. Therefore, noble moral values need to be taught so that present and future generations are able to behave according to the expected morals This research is a descriptive case study with a qualitative research design. The subjects of this study were students at Ad-Dimyati Integrated Vocational School Bandung. This study uses five data collection techniques, namely: observation, field notes, recording, document review, and interviews. Interrogation of noble moral values on Indonesian language lessons to form students' language skills in the Ad-Dimyati Integrated Vocational School is conducted through learning activities. The implementation of the interrogation of noble moral values on Indonesian language lessons to form students' language skills in Ad-Dimyati Integrated Vocational School is based on the potential, development and condition of students to master competencies that are useful for them. Implementation of the integration of noble moral values on Indonesian language lessons to form student language politeness using a multi-strategic and multi-media approach, adequate learning resources and technology, and utilizing the surrounding environment as a learning resource, in line with the vision of Ad-Dimyati Integrated Vocational School.
\end{abstract}

Keywords: noble moral values; immoral behavior; student language politeness; Integrated Vocational School (SMK Terpadu)

\section{A. INTRODUCTION}

The sharp dichotomy between secular and religious scholarship (Yinger, 1967) has broad implications for educational aspects in the Muslim community (Stambach et al., 2011), both concerning the way people view science and education, educational institutions, educational curricula, and people's behavior. In practice there is a distortion between the ideals of national education and the social reality that occurs (Balci, 2013).

Various national phenomena show alarming (Burton \& Higley, 1987) symptoms related to the morals of generations and the national elite. The thing that worries me more is that the moral anomalies are not a few that occur in the educational environment itself (Siegel, 2012, p. 173), even by educational actors. One indicator that shows the symptoms of a decline in the morals of the nation's generation can be seen from the practice of student manners which 
have begun to fade, among them we can see from the way their fellow students speak, their behavior towards teachers and parents, both in school and society, saying swear words that are not properly spoken by a student his age are often thrown out (Suganob-Nicolau, 2016).

One of the factors that causes low quality of language includes changes in the increasingly bad and complex situation of society. While language coaching which is of good quality or polite language does not get maximum attention from various levels of society. Therefore, anticipatory thinking about the future conditions of life of the nation has implications for the development of educational strategies that can shape a nation with polite character. Thus, efforts to develop polite language must be one of the general education goals or values (Tickle, 2011). Unkind language can give birth to communication gaps which create a bad situation in various environments both family, school and society. This is the explanation that brawls, drug abuse, and criminal acts among teenagers, are caused by the lack of better communication between family, school, and society (Masood \& Us Sahar, 2014).

The importance of learning noble moral values and nobility for all citizens (Kite, 2013) of the nation should not be denied anymore. A country or a nation can collapse because officials and some of their people behave immorally. Immoral behavior will lead to riots, confusion, irregularities and others that cause the destruction of a nation. Therefore, noble moral values need to be taught so that present and future generations are able to behave according to the expected morals (Carmody, 2012).

The main purpose of education is to produce a human personality that is intellectually mature, emotional, and spiritual. Therefore, the essential component of human personality is value and virtues. This value and virtue must be the basis for the development of human life that has individual and social civilization, goodness and happiness. Thus, education in schools should give priority to raising the values of life, and explain the implications for the quality of life of the community (Hakim, 2015).

In Law No. 20 of 2003 concerning the National Education System, it is stated that national education functions to develop capabilities and form a dignified character and national civilization in order to educate the nation's life, aiming to develop the potential of students to be faithful to The One Almighty God, noble, healthy, knowledgeable, competent, creative, independent, and a democratic and responsible citizen. Referring to these basic rules, formally efforts to prepare education, conditions, facilities / infrastructure, activities, and learning that lead to the formation of noble character and character of the young generation of the nation have a strong legal basis.

Polite language is the most appropriate tool used by students in communicating (Yulia, 2016). Children need to be nurtured and educated in polite language, because children are the next generation who will live according to their times. If the child is left to speak in a manner that is not polite, then it is not impossible that the polite language that already exists can be lost and then a generation that is arrogant, rude, and dry is born of ethical and religious values. Temporary observations show that the consequences of harsh and arrogant language expressions often lead to disputes and fights among students (Ulumudin, 2016). Conversely, those who are used to speaking politely and politely in general are able to act as good members of society. Such polite speech (Mills, 2003, p. 64) and good behavior (Marafi, 2012, p. 36) are the picture of a whole human being as explicit in the purpose of 
general education, namely a person with personality.

Based on the description above, it can be disclosed, that one of the factors that cause the lack of polite language in school is the lack of special polite language attention, from the school, family and community. Therefore this research is important because the language conditions at school are presumably unfavorable. If left by families, communities and schools, this will encourage the occurrence of violent, violent and dry behavior from ethical and religious values, as well as the loss of a sense of humanity, in other words, the overthrow of the national character that was previously an identity.

\section{B. METHOD}

This research is a descriptive case study with a qualitative research design. The subjects of this study were students at Ad-Dimyati Integrated Vocational School Bandung. This study uses five data collection techniques, namely: observation, field notes, recording, document review, and interviews. The research process is carried out in the process of teaching and learning activities by integrating the learning of noble moral values in Indonesian language learning material in learning plans, in learning materials, in learning activities, and in learning assessment activities.

\section{RESULT AND DISCUSSION}

\section{Language Learning}

The value of language transcendence is that language is a human nature. Consider for example the word of God "the Merciful. Teach al Qur'an. Creating people. Teach al-bayān "(Al Rahman, 1-4). Al-Shawkānī in Tafsīr Fath al Qadīr defines al-bayān as the ability to communicate (Al-Shawkānī, 2007, p. 1433). The principle of communication in Islam itself by drawing the word "qawl" concludes there are six principles, namely sadidan (QS. 4: 9; 33:70), balïghan (Qur'an 4:63), maysūran (Qur'an 17:28; 20:44), karīman (QS. 17:23), and ma'rūfan (Qur'an 4: 5). Thus, avoiding communication means contradicting human nature. This is the principle of transcendence that must be conveyed to students so that they realize that language is essentially God's command.

Among the three components of communication, the communicator is an important element (Coll, 2002, p. 33). In addition to having the nature of truth, honesty, virtue, and justice, a communicator must pay attention to his personality, honesty, intentions, thoroughness of the message conveyed, the validity of the source of his message, and study to find out his honesty. Therefore, a communicator must convey a message that is correct in addition to the language used even must be correct according to the rules (Karmakar \& Datta, 2012, p. 323).

Human communication can express itself, form a network of social interactions, and develop his personality (Patterson, 2006, p. 67). Failure to communicate is fatal both individually and socially. Individually, communication failures will cause frustration or other mental illness. Socially, communication failures inhibit mutual understanding, cooperation, tolerance, and hinder the implementation of social norms. Because it is impossible for humans not to speak and communicate, the human obligation is to use language as well as possible, as God has spoken lovingly to humans, as order received by Moses and Aaron for communicating 
politely to Ramses (Jazuli, 2006, p. 153; Qardhawi, 1998, p. 65). God's language can be expressed, through His word, but it can also be in the form of language that is implied through various natural phenomena.

Among several theories of politeness in language, Brown and Levinson's theories, in Deanda and Becerra (2014) are considered the strongest so that there are many users (Deanda \& Becerra, 2014, p. 308). In his theory, Brown and Levinson use face nosi or self-image (face). The term "face", which in this context is translated as face or self image, was originally used by Goffman in 1967 (Bedijs, Held, \& Maaß, 2014, p. 115). The word was originally a regional language vocabulary which later became a separate entry in English. As can be seen in the use of the term "losing face", face is an emotionally embedded term, and it can be eliminated, maintained, elevated, or stopped (attended) in interaction (Brown, Levinson, \& Levinson, 1989, pp. 1-2). Further, the interactions, both dyadic and triadic, in general people try to maintain their faces and also try to be vulnerable (vulnerability). It implies that saving face is a basic requirement that every member of the community knows that each other member expects, and generally it is the concern of every member (De Schuymer, De Groote, Striano, Stahl, \& Roeyers, 2011).

Social behavior and relational interests in the concept ahead relate to the core values of the character that are social and sourced from the heart, namely caring. It implies that the core value of character that is intended to be formed through the teaching of politeness is caring.

\section{Noble Moral Values}

According to Al-Ghazali (Wartini, 2015), it is noble or praiseworthy to eliminate all despicable customs that have been outlined in the Islamic religion and keep away from these disgraceful deeds, then get used to good habits, do them and love them. Whereas according to Quraish Shihab, noble character is morality which uses the provisions of Allah as a benchmark and a measure of good behavior must refer to the provisions of Allah. If someone has a right and strong aqeedah, then he will easily implement sharia consistently. Furthermore, aqeedah and sharia will produce morals. Morals are human behavior that appears and does not seem like a heart activity (Shihab, 1996, p. 336).

Morals are not limited to manners to fellow human beings but more broadly, which includes relations with God (habl min al-lāh), relations with fellow humans (habl min al-nās), and relations with the surrounding environment (habl min al-āalam). Examples of habl min al-lāh morals are pray, hajj, prayer, dhikr, thanksgiving favors etc. Examples of habl min al-nās morals are visiting people who are sick, helping each other, eroding revenge and forgiving each other. Whereas examples of habl min al-'älam such as not littering, supporting animals, being energy efficient, making the best use of natural resources, etc.

Education as moral values as an aid to students to realize and experience values and place them integrally in their whole lives can be found in the subjects. Value education is not only a special program taught through a number of subjects, but also covers the whole process of education. In this case, who instill value to students is not only the teacher of value and moral education and not only when teaching it, but when and everywhere, value must be an integral part of life (Mulyana, 2004, p. 119). 
Noble character is the nature or behavior of a person in accordance with the values of Islamic teachings found in the Qur'an and Hadith. The aspects that influence the formation of one's morality are: instinct, environment, descendants, customary habits, and al-qiyam: an understanding of Islamic values contained in the Qur'an and Hadith, can practice it, so that unwittingly those values are united in their personality and noble character is formed (Ismail, 2016).

Noble character means the characteristics or behavior that are in accordance with the norms of Islamic teachings. We can imitate noble morals from the example of the personal figure of the Prophet Muhammad. He fulfilled his obligations and fulfilled his mandate, told humans to be straight to monotheism, leaders of the people without favoritism, and various other noble qualities. With various characteristics and actions, in various fields and circumstances he became a role model and example for humans (Nazir, 2011, p. 65).

Education is a regeneration process (Hopkins, 2013, p. 310) that is carried out by developing affective, cognitive and psychomotor domains. Every student has a competency baseline that needs to be developed. Every level of education provides traces in every student's life, and is imprinted in the soul of the student and tangible in the form of behavior. The success of the educational process is reflected in the values of noble character in students (FIP UPI, 2007, p. 247), including: honesty, sincerity, humility, compassion, discipline, frugal confidence, never give up, fair, positive thinking, independent, peace-loving, tolerance, emotional control, citizenship, responsibility, creative, polite and polite speaking (Thomsen, 2002, p. 47). Such noble character formation is certainly influenced by many factors, including: family environment, peer environment, technological development factors, and schools as formal institutions. Individuals involved in this matter are certainly expected to have competency according to their proportions (Anwar, 2015, p. 16).

\section{Integrate Indonesian Language Learning Materials with Noble Moral Values at Integrated Vocational School (SMK Terpadu) Ad-Dimyati}

From the Interview of the researcher with the Head of Ad-Dimyati Integrated Vocational School, it is found that the faith and piety are universal, but in practice faith and piety will manifest in cognition, apection, and psychomotor. In other languages, the faith and piety of students must be tangible and knowledge, attitudes and speech, as well as human behavior. Well-spoken language is part of the refraction of faith and piety.

Language learning, in the context of fostering faith and piety, as mentioned earlier can be done by selecting teaching materials that are in accordance with the principles of fostering faith and piety and fostering language teachers about faith and piety at Ad-Dimyati Integrated Vocational School. Thus, Indonesian language teachers in addition to teaching languages also teach Islamic teachings and morals to speak both explicitly and implicitly. The second way emphasizes the role of the teacher in transforming religious values through learning Indonesian. Well, which transcendent foundation should be given to students in order to integrate language learning.

This classification is based on the group of skills found in Indonesian language learning, namely: 
a) In reading learning, religious foundations can be transformed based on the values contained in letter al Alaq 1-5. The five verses are the first revelations received by the Prophet Muhammad when he was arrested as a prophet and apostle. Based on the verse above, reading is a must. Without reading humans will be blind to science, because reading is a window to science. In reading learning, the teacher inserts the above verse as a reward so that students do not just read because they want to get good grades or are told by the teacher. Students should be made aware that bringing is God's command. Thus, reading is a form of worship.

b) Listening is a media to absorb information in the form of ideas, ideas, thoughts, wishes, complaints etc. In the learning process, the teacher can insert the meaning of letter 47:21 and letter 7: 157.

c) Speaking. In Islamic teachings a good conversation, containing benefits for other parties, is better in value than sadaqah followed by insults to the recipient. This is the transcendental value of speaking skills. For this reason, we need to be given a polite way of speaking (pragmatics), so that oral communication can benefit others (Qur'an 2: 163).

d) Writing is part of da'wah, as long as the information provided can help others. Writing is an effective method for conveying information openly. The moral basis for writing can be seen in letters 16: 125 , letters 16: 10-11, letters 3:17, letters 16:96 etc. Many capital obligations to write a truth. Even the Messenger of Allah said that an unorganized truth would be defeated by an organized godliness. Writing down the truth is a step to organize the truth, as long as in writing the principles of Islam are upheld.

e) In appreciating literary works, in addition to choosing literary works a moral foundation is also needed to imitate other people's behavior correctly. This moral foundation can be seen in letters 16:44, etc. The selection of literary works is part of the steps to introduce moral values to students.

\section{Implementation of the Integration of Noble Moral Values in Indonesian Language Learning Materials for Fostering Student Language Wisdom at Integrated Vocational School (SMK Terpadu) Ad-Dimyati}

One of the superiorities of education at Ad-Dimyati Integrated Vocational School and at the same time that distinguishes it from other educational institutions is the implementation of a curriculum that combines national curriculum with boarding school curriculum which aims to produce students who are virtuous, able-bodied, knowledgeable and creative and dynamic thinking.

Based on the educational objectives to be achieved, religious education is not only done through the field of religious studies, but must also be contained in every general subject. Through all these subjects it is expected that the transfer of values, not just Islamic transfer can work well. There needs to be an integralalization of religion at every educational activity.

Interview of the researcher with the Head of Ad-Dimyati Integrated Vocational School, obtained the following information: 


\begin{abstract}
"Actually, the implementation of integral-based education in this school can be seen from all dimensions of daily activities of students (and santri) and teachers in this school united in a universal unity of Islamic understanding by making it Islam as a Way of Life without a dichotomous viewpoint between religious or non-religious things. Mothers can prove themselves in the field that the school administrators or their teachers are also responsible for the good or not the learning process in Vocational Schools, including the control or supervision of them towards students. In this context; that is where the morality of behavior and knowledge of students is not only the responsibility of one formalized lesson but all parties are responsible which are bound in communal unity."
\end{abstract}

The results of the researchers' observations indicate that in general the teachers of AdDimyati Integrated Vocational School expect students to be able to understand and have good reasoning power in understanding and living the lessons that have been delivered, to create modern Islamic thought patterns in accordance with the objectives of Ad-Dimyati Integrated Vocational School. Giving lessons that are of one-way nature (monologue) are not able to produce outputs that are ready to be independent. For that the teacher provides opportunities and encouragement to students to be active and carry out all activities without being burdened with feelings of fear of making mistakes.

Education process at the Ad-Dimyati Integrated Vocational School is also directed to foster a sense of care for students about the problems that develop in their society. For that education activities must be designed so that students can be closer to the ummah, so that they know clearly the situation. Education should not become an ivory tower, but should be a water tower. Education should not be directed at producing elite groups far from the ummah. It is precisely what is expected is the result of students who are close to the ummah, able to understand and be able to offer solutions or various problems faced by the ummah.

The curriculum implementation at the Ad-Dimyati Integrated Vocational School was held through learning activities. The daily learning activities begin with the Duha prayer simultaneously at the school mosque, followed by home room session activities which are guided directly by the homeroom teacher.

The implementation of the integration of noble moral values in Indonesian language lessons at Ad-Dimyati Integrated Vocational School, in general, can be seen from: 1) learning planning, 2) mastery of study fields, 3) use of methods, strategies and techniques, 4) classroom management, 5 ) use of media, 6 ) evaluation of results and 7) efforts to improve quality carried out at Ad-Dimyati Integrated Vocational School.

The results of the observations conducted by the researcher indicate that the implementation of the integration of noble moral values on Indonesian language lessons at Ad-Dimyati Integrated Vocational School does not increase or decrease the time allocation set in the existing Indonesian Language curriculum. The time for implementing the integration of noble moral values in Indonesian language lessons is done using existing learning allocations with little presentation settings. The implementation of the integration of noble moral values in Indonesian Language lessons is held every Monday to Wednesday, namely when Indonesian Language teachers provide lessons to Class X-XII students.

The findings of the researchers about the implementation of the integration of noble moral values in Indonesian Language lessons at Ad-Dimyati Integrated Vocational School, among others, can be seen based on several indicators, namely: 
First, learning planning. The implementation of the integration of noble moral values on Indonesian Language lessons at Ad-Dimyati Integrated Vocational School basically still refers to the guidelines for developing syllabus that has been implemented in the school. Interviewing researchers with Indonesian Language Teachers, obtained the following information:

\begin{abstract}
"The development of the Indonesian language syllabus which was developed basically was not much changed from the design that was there except to include and supplement Islamic values in the existing national curriculum. The aspects contained in the syllabus of the integrated curriculum are general subjects with religion that will be developed in line with the existing curriculum design."
\end{abstract}

The implementation of Indonesian language learning developed basically also refers to the model of learning plans that are commonly carried out by teachers in other schools by incorporating ideas or concepts of integrating general subjects with religion as stated above. The important thing in developing a plan for implementing learning as an implementation of curriculum implementation is to develop the process of learning activities.

Based on the results of interviews with Indonesian Language Teacher informants, an overview of the implementation of the learning process in the classroom was obtained as a curriculum implementation, namely the following things were done:

1. Introduction
a. Pre-test
b. Clarification of Learning Objectives
c. Explain the subject matter to be studied
d. Describe procedures and technical learning activities
e. Motivates students' readiness to enter the lesson

\title{
2. Learning Process
}
a. Exploration of subject matter material
b. Group discussion to conduct analysis, synthesis and evaluation of material and the relationship of material to general subjects with religion
c. Make group reports.
d. Class discussion
e. Teacher explanation

3. Closing
a. Post test
b. Make conclusions and suggestions

The results of observations of researchers when learning took place in class IX of Ad-Dimyati Integrated Vocational School showed that in Indonesian language learning, the teacher was responsible for the overall learning activities.

Second, the implementation of learning that integrates noble moral values on Indonesian language lessons does not increase or reduce the time allocation set in the existing science and technology subject curriculum. The time for integrating noble moral values in Indonesian language lessons is done using the allocation of Indonesian language lessons. 
In this case, students get quality education services, and get the opportunity to express themselves freely, dynamically and pleasantly.

Interviews of researchers with several students of the Ad-Dimyati Integrated Vocational School obtained the following information::

\begin{abstract}
"We here receive good service during the Indonesian language learning process. They do not feel hesitant or get pressure from the teacher to ask questions, express themselves in front of the class, be given the freedom to express opinions, and a pleasant learning atmosphere. This condition is carried out outside the classroom, including when they are in a dormitory environment, students do not feel burdened with the rules set by the school, and apply learning such as using good and correct languages when talking with friends. friend."
\end{abstract}

The curriculum implemented at the Ad-Dimyati Integrated Vocational School is based on upholding the five pillars of learning. The curriculum implementation at Ad-Dimyati Integrated Vocational School is based on five student pillars, namely: (a) learning to believe and fear God Almighty, (b) learning to understand and appreciate, (c) learning to be able to effectively implement and act, (d) learning to live together and be useful to others, and (e) learning to build and find identity, through an active, creative, effective and enjoyable learning process.

Learning that always links subject matter with Islamic values, implementation of mentoring activities and halaqoh, and habituation of worship services in duha, zuhr and ashar prayers in congregation at the mosques in the two researched schools shows that character education in Ad-Dimyati Integrated Vocational School can be well implemented.

The implementation of the integration of noble moral values on Indonesian language lessons at Ad-Dimyati Integrated Vocational School allows students to receive services that are in the form of improvement, enrichment, and / or acceleration in accordance with the potential, developmental stage, and condition of students while taking into account the integrated personal development of participants students who are godly, individualized, social, and moral.

Learning carried out at Ad-Dimyati Integrated Vocational School using a multistrategic and multimedia approach, adequate learning resources and technology, and utilizing the surrounding environment as a learning resource, in line with the vision of Ad-Dimyati Integrated Vocational School. The results of the interview with the head of the Ad-Dimyati Integrated Vocational School were obtained as follows:

\footnotetext{
"The implementation of learning at the Ad-Dimyati Integrated Vocational School always links aspects of aqliyah, jasadiyah, and ruhiyah. Learning is also based on RPP and uses LCD, internet and e-learning facilities. Outside classroom learning is also a scheduled activity at Ad-Dimyati Integrated Vocational School."
}

The multi-strategy approach in implementing the curriculum at Ad-Dimyati Integrated Vocational School follows the established work program, both short, medium and long term programs. The short-term program of the Ad-Dimyati Integrated Vocational School is a work program that must be achieved within one to five years in an effort to make a more concrete work program based on existing objective conditions. and learning at Ad-Dimyati Integrated Vocational School. 
The mid-term program at Ad-Dimyati Integrated Vocational School is a work program that must be achieved within a period of 15 (fifteen) to 30 (thirty) years, in an effort to create a more concrete work program based on existing capabilities.

Long-term program is a work program that must be achieved by Ad-Dimyati Integrated Vocational School within a period of 30 (thirty) to 50 (fifty) years, as an effort to provide direction for the implementation of the Ad-Dimyati Integrated Vocational Program in general, namely improving quality and the quality of education and learning at Ad-Dimyati Integrated Vocational School so that students have moral character, have good bodies, are knowledgeable and creative, innovative and dynamic.

The implementation of integrating noble moral values on Indonesian Language lessons at Ad-Dimyati Integrated Vocational School is also supported by the competence of the teacher. The results of observations of the researchers found that mastery and understanding of the curriculum model that combines general subjects with religion is relatively sufficiently understood by the teachers at Ad-Dimyati Integrated Vocational School.

In addition, mastery of material, concepts and values of imtaq, especially those relating to material, concepts and theories taught at Ad-Dimyati Integrated Vocational School, are relatively good. This is because of the varied educational background and knowledge of the teachers, as well as from good educational institutions.

\section{CONCLUSION}

The implementation of the interrogation of noble moral values on Indonesian language lessons to form students' language skills in the Ad-Dimyati Integrated Vocational School was conducted through learning activities. The implementation of the interrogation of noble moral values on Indonesian language lessons to form students' language skills in Ad-Dimyati Integrated Vocational School is based on the potential, development and condition of students to master competencies that are useful for them. Implementation of the interrogation of noble moral values in Indonesian language lessons to form student language politeness using a multistrategic and multimedia approach, adequate learning resources and technology, and utilizing the surrounding environment as a learning resource, in line with the vision of the Dimyati Integrated Vocational School.

\section{REFERENCES}

Al-Shawkānī, M. b. 'Alī b. M. (2007). Tafsìr Fath al Qadīr. Retrieved from http://archive.org/details/waq105908

Anwar, S. (2015). Management Of Student Development. Tembilahan: Indragiri TM.

Balci, B. (2013). Between secular education and Islamic philosophy: the approach and achievements of Fethullah Gülen's followers in Azerbaijan. 1(1), 107-116.

Bedijs, K., Held, G., \& Maaß, C. (2014). Face Work and Social Media. LIT Verlag.

Brown, P., Levinson, S. C., \& Levinson, S. C. (1989). Politeness: Some Universals in Language Usage. Cambridge: Cambridge University Press.

Burton, M. G., \& Higley, J. (1987). Elite Settlements. American Sociological Review, 52(3), 295-307. https://doi.org/10.2307/2095351 
Carmody, C. (2012, November 8). Considering future generations - sustainability in theory and practice | Treasury.gov.au. Retrieved from https://treasury.gov.au/publication/economic-roundup-issue-3-2012-2/economicroundup-issue-3-2012/considering-future-generations-sustainability-in-theory-andpractice

Coll, G. (2002). Graphic Communication: Applying Principles. New York: Prentice Hall.

De Schuymer, L., De Groote, I., Striano, T., Stahl, D., \& Roeyers, H. (2011). Dyadic and triadic skills in preterm and full term infants: A longitudinal study in the first year. Infant Behavior and Development, 34(1), 179-188. https://doi.org/10.1016/j.infbeh.2010.12.007

Deanda, D., \& Becerra, R. M. (2014). Violence: Diverse Populations and Communities. Routledge.

FIP UPI, T. P. I. P. (2007). ILMU \& Aplikasi Pendidikan. Jakarta: Grasindo.

Hakim, A. (2015). Contribution of Competence Teacher (Pedagogical, Personality, Professional Competence and Social) On the Performance of Learning. The International Journal Of Engineering And Science (IJES), 4(2), 1-12. https://doi.org/09.1913/42301012

Hopkins, R. (2013). Empowering Education. Winchester - Washington: John Hunt Publishing.

Ismail, I. (2016). Character Education Based on Religious Values: an Islamic Perspective. Ta'dib: Journal of Islamic Education (Jurnal Pendidikan Islam), 21(1), 41-58.

Jazuli, A. S. (2006). Hijrah dalam Pandangan Al-Quran. Jakarta: Gema Insani. Karmakar, A., \& Datta, B. S. (2012). Principles and Practices of Management and Business Communication. New Delhi: Pearson Education India.

Kite, V. (2013, July 22). The Nobility of Teaching. Retrieved from Lab 207 website: https://www.thelabatcma.com/the-nobility-of-teaching/

Marafi, N. (2012). The Intertwined Conflict: The Difference Between Culture and Religion. n.p.: Xlibris Corporation.

Masood, S., \& Us Sahar, N. (2014). An exploratory research on the role of family in youth's drug addiction. Health Psychology and Behavioral Medicine, 2(1), 820-832. https://doi.org/10.1080/21642850.2014.939088

Mills, S. (2003). Gender and Politeness. Cambridge University Press.

Mulyana, R. (2004). Mengartikulasikan Pendidikan Nilai. Bandung: Alfabeta.

Nazir, A. K. (2011). Balanced Personality. Bloomington: Trafford Publishing.

Patterson, M. L. (2006). The SAGE Handbook of Nonverbal Communication. Thousand Oaks - London - New Delhi: SAGE.

Qardhawi, Y. (1998). Kebangkitan Islam dalam perbincangan para pakar. Gema Insani.

Shihab, M. Q. (1996). Wawasan Al-Quran: Tafsir Tematik atas Pelbagai Persoalan Umat. Bandung: Mizan Pustaka.

Siegel, L. J. (2012). Criminology: Theories, Patterns, and Typologies. Belmont: Cengage Learning.

Stambach, A., Marshall, K., Nelson, M. J., Andreescu, L., Kwayu, A. C., Wexler, P., ... El Bilawi, H. (2011). Religion, Education, and Secularism in International Agencies. Comparative Education Review, 55(1), 111-142. https://doi.org/10.1086/657650 
Suganob-Nicolau, M. F. (2016). Swear words among young learners: A case study of the elementary students. Indonesian JELT, 11(2), 117-132-132.

https://doi.org/10.25170/ijelt.v11i2.825

Thomsen, K. (2002). Building Resilient Students: Integrating Resiliency Into What You Already Know and Do. Thousand Oaks: Corwin Press.

Tickle, L. (2011, October 3). Research demonstrates how the use of bad language can alter our behaviour. The Guardian. Retrieved from https://www.theguardian.com/education/2011/oct/03/research-demonstrateslanguage-affects-behaviour

Ulumudin, I. (2016). KAJIAN FENOMENA TAWURAN PELAJAR PENDIDIKAN MENENGAH. JURNAL ILMIAH MIMBAR DEMOKRASI, 15(2), 40-55.

Wartini, A. (2015). EDUCATION CHARACTER IN VIEW OF AL-GHAZALI AND ITS RELEVANCE WITH THE EDUCATION CHARACTER IN INDONESIA. Ta'dib: Journal of Islamic Education (Jurnal Pendidikan Islam), 20(2), 293-310.

Yinger, J. M. (1967). Pluralism, Religion, and Secularism. Journal for the Scientific Study of Religion, 6(1), 17-28. https://doi.org/10.2307/1384190

Yulia, M. F. (2016). POLITENESS ISSUES IN COMMUNICATION OVER TEXT MESSAGES. Proceedings of ISELT FBS Universitas Negeri Padang, 4(2), 54-61. 